\title{
THE EFFECT OF ORGANIC-Cr DIETARY SUPPLEMENTATION ON STRESS RESPONSE IN TRANSPORT-STRESSED BEEF CATTLE
}

\author{
U. H. Tanuwiria, U. Santosa, A. Yulianti and U. Suryadi \\ Faculty of Animal Husbandry, Padjadjaran University \\ Jl .Raya Bandung-Sumedang Km 21. Jatinangor, Sumedang 45363 \\ CorrespondingE-mail: uhtanuwir@yahoo.co.id
}

Received March 14, 2011; Accepted May 7, 2011

\begin{abstract}
Transportation over long distances resulted in stress at animal. Under these circumstances, animal usually manifest depression and the impact on physiological condition changes and loss of body weight. The objectives of the research were to examine effect supplementation of organic-Cr type into diets in transport-stress beef cattle on physiological condition, haematochemical (included were haematological condition and blood chemical) and body weight changes. The experiment was conducted using 16 beef cattle those were transported by truck for a distance of $400 \mathrm{~km}$ from Malangbong to Tangerang. The experiment was arranged by Completely Randomized Design with four treatments and four replications. The dietary treatments consisted of R0 (basal diet without $\mathrm{Cr}$ supplemented), R1 (R0+3ppm organic-Cr resulted of alkali hydrolysis), R2 (R0+3 ppm organic-Cr resulted from bioprocess), R3 (R0+3 ppm organic-Cr resulted from bioremediation). The result indicated that type of organic-Cr supplementation at $3 \mathrm{ppm}$ in diet did not influence physiological condition, haematochemical and body weight at beef cattle transported for seven hours. There was indication that beef cattle fed on control diet (without $\mathrm{Cr}$ ) showed a stress symptom, their loss of body weight were higher (5.41\%) compared to beef given diet contains organic-Cr $(3.72 \%, 5.04 \%$ and $4.83 \%$, respectively for R1, R2 and R3).

Keywords: beef cattle, organic-Cr, stress, transportation
\end{abstract}

\section{INTRODUCTION}

Transportation over long distances is a significant cause of stress in animal. This effect is exacerbated by denying the animals feed and water during transportation. These circumstances results in reduced microbial fermentation in the rumen and decreased alimentary canal motility (Al-Mufarrej et al., 2008) and metabolic dysfunction (Parker et al., 2003).

Transportation stress in animal in physiologically occurred when animal can not maintain homeostasis process that needs some metabolites like glucose, electrolyte (for example $\mathrm{Na}^{+}, \mathrm{K}^{+}, \mathrm{Cl}^{-}$) and water to overcame the stress. As consequence, during transportation, animal must be fed on dietary supplement of glucose source to avoid glycogen catabolism. Transport-induced immunosuppression and resulting in productivity losses (Colditz and Hennessy, 2001). In transportation studies using Bos taurus calf model, leukocytosis associated with neutrophilia has been reported (Kannan et al., 2000 and Stanger et al., 2005). Such responses may be indication of a physiological or pathological change, but also may indicate an epinephrineinduced response (Tyler and Cummins, 2003; Nairab and Bonneaub, 2006).

Chromium $(\mathrm{Cr})$ is essential microelement related to insulin activity, mixed up with glucose metabolism, protein, and fat at animal tissue. As the active component from Glucose Tolerance Factor (GTF), Cr is required as cofactor insulin for transported glucose from circulation into peripheral tissue (Anderson and Kozlovsky, 1985; Mertz, 1992). The other research shows addition $\mathrm{Cr}$ (chelate-amino acid) increases the milk production (Yang et al., 1996) and improves diet efficiency in beef experiencing of stress (Chang and Mowat, 1992), and improves insulin cordage with specific receptor at target organ (Anderson and Kozlovsky, 1985; Parker et al., 2007). In Cr deficient livestock, $\mathrm{Cr}$ supplementary will improve the usage of glucose by insulin for muscle forming and adipose tissue (McNamara and Valdez, 2005). According to Knowles and Warriss (2000), long transportation (18-24 hours) can cause beef cattle loss of body weight by $3 \%$ - 
$11 \%$.

Supplementation of $\mathrm{Cr}$ in the diet should be in form of organic-Cr, because nontoxic and 25-30\% can be absorbed by the body (Chang and Mowat, 1992). Organic-Cr is complex $\mathrm{Cr}$ that bound in protein. Structure GTF is compiled from complex between $\mathrm{Cr}^{3+}$ with 2 acid molecules of nicotinate and 3 amino acids that is glutamate, glycine and cystein (Linder, 1992). Addition Cr into the diet will be useful, specifically for improving immunity system at livestock experienced stress of transportation (Al-Mufarrej et al., 2008). The objectives of the present study were to explore the effect of organic-Cr dietary supplementation on stress responses of transport-stressed beef cattle.

\section{MATERIAL AND METHODS}

\section{Animals, Diet and Experimental Design}

This experiment was conducted to 16 Brahman Cross bulls $(469.1 \pm 32.35 \mathrm{~kg})$, transported by truck for a distance of $400 \mathrm{~km}$ from Malangbong to Tangerang, or equal to seven hours transportation time. Beef cattle were given a diet containing $3 \mathrm{ppm} \mathrm{Cr}$ for three days prior to be transported. Type of organic-Cr that given was organic-Cr result of skin waste hydrolysis by alkali $\mathrm{NaOH}$, organic-Cr result of Saccharomeces cereviseae bioprocess, and organic-Cr result of Duckweed bioremediation.

The research was arranged based on completely randomized design with four treatments and four replications, respectively. The dietary treatment were $\mathrm{R} 0=$ control diet without Cr supplemented (containing 30\% rice straw, $70 \%$ concentrate), $\mathrm{R} 1=\mathrm{R} 0+3 \mathrm{ppm}$ organic-Cr by alkali hydrolysis, $\mathrm{R} 2=\mathrm{R} 0+3 \mathrm{ppm}$ organic-Cr by Saccharomeces cereviseae bioprocess, $\mathrm{R} 3=\mathrm{R} 0+$ $3 \mathrm{ppm}$ organic-Cr by Duckweed bioremediation. All of diets contained $82.5 \%$ dry matter, $11.3 \%$ ash, $9.8 \%$ crude protein, $31.1 \%$ crude fibre and $69.8 \% \mathrm{TDN}$.

\section{Sample Collection and Analysis}

Variables perceived were physiological and haematochemical (included were haematological condition and blood chemical), loss of body weight and percentage of carcass. Measurement was conducted after arrive at target location. The body weight change was measured by weighing the body weight at start and after transportation.

Parameter of physiological condition were body temperature, respiration frequency, and pulses frequency. Haematochemical was measured by taking blood from vena jugularis using Li-Heparin LH (9ml) tube (Sarstedt Inc., Newton, NC). Plasma from each sample was collected and stored at $-20^{\circ} \mathrm{C}$ until needed for analysis of blood electrolyte (Na, K). Haematological (included value haematocrit, haemoglobin, erythrocyte, and leukocyte) measured as follows : (a) haematocrit was measured by centrifugation of whole blood in capillary haematocrit containing heparin at 3000 rpms for 15 minutes. The value of haematocrit was determined by using microcapillary reader, (b) Haemoglobin ( $\mathrm{Hb})$ measurement was conducted by the method of Haemometer Sahli. (c) erythrocyte cell was determined by using haemocytometer. (d) Measurement of leucocytes cells was similar to the method of erythrocyte measurement.

Blood chemical included were glucose, Chromium (Cr), Potassium (K) and Sodium (Na). Glucose concentration of the blood plasma was determined using glucose oxidase/peroxidase enzyme and dianisidine dihydrochloride (Sigma) as described previously (Regmi et al., 2008), and the absorbance was determined by a microplate spectrophotometer (UV-1601). Net glucose disappearance was calculated by subtracting the amount of glucose in incubation media of treatment flasks from that of 0 -min control.

The $\mathrm{Cr}, \mathrm{K}$ and $\mathrm{Na}$ in the blood plasma were determined by commercial kits, absorbance of each sample was read versus blank tube by UV1601 Spectrophotometer at $600 \mathrm{~nm}$ wavelength. The body weight loss was measured from difference of body weight before and after transportation.

\section{Statistical Analysis}

Data were analyzed by analysis of variance (Steel and Torrie, 1981) using the SPSS ver 12 to know the effect of organic-Cr on stress response (SPSS, 2004).

\section{RESULTS AND DISCUSSION}

The beef cattle that suffer stress can be seen from physiological condition like body temperature, rate of respiration and rate of pulses. At this research, researchers investigating effect organic-Cr on transport stress in cattle have primarily employed beef cattle model. Beef cattle are commonly transported by commercial truck carriers. This study showed that there were no 
significant effect $(\mathrm{P}>0.05)$ of organic-Cr dietary supplementation on transport-stressed beef cattle (Table 1). Some studies also showed that $\mathrm{Cr}$ had no significant effects on growth performances (Van de Ligt et al., 2002; Mostafa-Tehrani et al., 2006).

The contrary results suggested that both transportation-related handling and travel have been identified as potential stressful events for cattle (Feuz and Umberger, 2003), and recent literature reviews addressed the potential impact of transportation on cattle health and performance (Eicher, 2001; Swanson and Morrow-Tesch, 2001; Fike and Spire, 2006), and increasing reactive oxygen species (ROS) include superoxide anion, hydrogen peroxide and derivative hydroxyl radical and hydroxide (Zheng et al., 2010).

Transportation has been associated with increasing of morbidity, stress responses and immune response (Stanger et al., 2005), reducing body weight, and reduces physiological condition (White et al., 2009). PUFA dietary supplementation not significantly to performance of transported-stressed beef cattle (Araujo et al., 2010).

Effect of $\mathrm{Cr}$ on transport-stressed beef cattle has been reported. Kegley et al. (2000) reported that supplemental $\mathrm{Cr}$, as chromium-L-methionine, increased glucose clearance rate after an insulin infusion and increased the insulin response to an intravenous glucose challenge in growing calves with functioning rumens. Vincent (2004) reported that various trivalent chromate compounds have been used as nutritional supplements, weight-loss agents, and muscle-development agents in humans and as feed additives in domestic animals. Wang et al. (2009) showed that trivalent chromium (Cr (III)) is a component of GTF and is vital in carbohydrate, fat, and protein metabolism presumably by potentiating the action of insulin.

The effects of supplemental organic-Cr on

Table 1. Stress Response of Transport-stressed Beef Cattle

\begin{tabular}{|c|c|c|c|c|}
\hline \multirow{2}{*}{ Item } & \multicolumn{4}{|c|}{ Treatment } \\
\hline & R0 & $\mathrm{R} 1$ & $\mathrm{R} 2$ & $\mathrm{R} 3$ \\
\hline \multicolumn{5}{|l|}{ Performance } \\
\hline Lose weight (\%) & 5.41 & 3.72 & 5.04 & 4.83 \\
\hline Carcass (\%) & 53.70 & 54.20 & 54.30 & 54.20 \\
\hline \multicolumn{5}{|l|}{ Some Physiological Condition } \\
\hline Body temperature $\left({ }^{\circ} \mathrm{C}\right)$ & 39.0 & 38.5 & 39.0 & 39.3 \\
\hline Rate of respiration per minute & 48.8 & 55.0 & 55.1 & 47.1 \\
\hline Rate of pulses per minute & 103.9 & 111.7 & 100.0 & 96.4 \\
\hline \multicolumn{5}{|l|}{ Haematochemical } \\
\hline Erythrocyte $\left(\mathrm{x} 10^{6}\right.$ cell/mL) & 842 & 718 & 821 & 660 \\
\hline Leucocyte $\left(\times 10^{3}\right.$ cell $\left./ \mathrm{mL}\right)$ & 81 & 69 & 82 & 80 \\
\hline Hematocrit (\%) & 34.40 & 29.00 & 33.60 & 34.20 \\
\hline Haemoglobin (\%) & 82.50 & 74.20 & 79.20 & 71.90 \\
\hline Blood Glucose (mmol/L) & 31.25 & 56.25 & 48.25 & 40.88 \\
\hline Sodium (Na, ppm) & 0.34 & 0.33 & 0.33 & 0.34 \\
\hline Potassium (K, ppm) & 0.03 & 0.03 & 0.03 & 0.03 \\
\hline Cromium (Cr, ppm) & 2.21 & 2.21 & 2.22 & 2.22 \\
\hline
\end{tabular}

$\mathrm{R} 0=$ control diet without $\mathrm{Cr}$ supplemented, $\mathrm{R} 1=\mathrm{R} 0+3 \mathrm{ppm}$ organic-Cr by alkali hydrolysis, $\mathrm{R} 2=\mathrm{R} 0+3 \mathrm{ppm}$ organic-Cr by Saccharomeces cereviseae bioprocess, $\mathrm{R} 3=\mathrm{R} 0+3 \mathrm{ppm}$ organic-Cr by Duckweed bioremediation 
the performance (carcass percentage and body weight) are presented in Table 1 . There were no significant $(\mathrm{P}>0.05)$ effect of organic- $\mathrm{Cr}$ on carcass percentage and body weight. The role of $\mathrm{Cr}$ in regulation of body composition is still controversial. Cr-Pic is the most widely used organic chromium complex to increase lean body mass or carcass leanness.

Wang et al. (2007) reported the carcass effects of trial comparisons and found a mean increase in longissimus muscle area of $2.7 \mathrm{~cm}^{2}$ (about 7\%; with 13 numerically positive responses out of 15 comparisons) and a mean reduction in $10^{\text {th }}$ rib backfat depth of $3.3 \mathrm{~mm}$ (about 13\%; with 13 positive responses out of 15 comparisons). The lack of a consistent response may be relate to $\mathrm{Cr}$ levels of the diets, $\mathrm{Cr}$ status of subjects, and amino acid levels of diet (Zha et al., 2007).

In the present study, supplementation of 3 ppm $\mathrm{Cr} / \mathrm{kg}$ diet decreased the lose body weight and increased carcass percentage, although not significant with control groups. These results were not in line to the striking effect on carcass composition of finishing pigs (Wang and $\mathrm{Xu}$, 2004), which implicated that $\mathrm{Cr}$ nanoparticle may be a more bioavailable source of $\mathrm{Cr}$ and potentially be used as an effective carcassmodifier for animals.

Data in Table 1 showed that effect of various organic-Cr in diet on physiological condition of beef cattle i.e. body temperature, rate of respiration and rate of pulses at beef were not significantly different. Body temperature of beef were ranged at $38.5-39.3^{\circ} \mathrm{C}$, rate of respiration were 47.1-55.1 times per minutes, and rate of pulses were 96.4-111.7 times per minutes that were not significantly different. In another words, source type $\mathrm{Cr}$ was not influence the physiological condition of beef cattle transported for seven hours.

The haematological value are often used as guideline of livestock health condition. Red blood count relates to ability in transporting nutrient to all body cells, while leucocyte amount relates to the immunity, haematocrit relates to plasma ratio with blood cell, and haemoglobin relates to ability oxygen transport to whole body. The value of beef cattle haematochemical that given diet contains various of organic-Cr after transportation is presented at Table 1.

Table 1 showed that addition organic-Cr into beef diet did not influence $(\mathrm{P}>0.05)$ haematochemical value. Nevertheless there was indication that red blood count and haemoglobin at $\mathrm{R} 0$ was higher than that of given organic-Cr in their diets. This condition indicated that beef cattle receiving control diet (R0) experienced stress as indication of haemoglobin level. Haemoglobin plays a part in oxygen supply that required by animal if they experiences of stress.

Direct effect of stress transportation consequence is decreasing of body weight. Beef cattle given diet containing $\mathrm{Cr}$ generally loss their body weight smaller than beef under control diet (R0). Among type of organic-Cr, in the organic-Cr that was processed by alkali hydrolysis method gives impact anti stress better than other organic$\mathrm{Cr}$. The best effects occured in the hydrolysis of organic-Cr low solubility of the company enable the consequences occurred either initial rumen (7.18\%) and also up to the abomasum (22.27\%) compared to the treatment of organic-Cr produce from bioprocess-Cr and bioremediation. Meaningful this condition that organic-Cr was more absorbable and exploited by the body for further metabolism to gluconeogenesis process.

Transportation effects in this research was not clearly emerge, in which this condition were related to long time of transportation conducted only seven hour. Knowles et al. (1999) recommend long time of transportation was ideally 24 hour with diet and drinking water available to speed up physical recovery after transportation. Addition $\mathrm{Cr}$ was not influences body weight or score of body condition at beef cattle due to heat grasp (Al-Saiady et al., 2004)

This study showed that organic chromium supplementation increased the blood glucose (Table 1). Therefore, organic-Cr was a bioavailable source of chromium, altering glucose and insulin metabolism, especially in the cell membrane transport. Odore et al. (2004) and Gupta et al. (2007) stated that $\mathrm{Cr}$ as chromium propionate had a greater effect on increasing insulin secretion than on insulin sensitivity. An observation using rat pancreas showed that supplemental dietary $\mathrm{Cr}$ as chromium chloride increased insulin secretion. Further work must be conducted to elucidate the impact of supplemental bioavailable $\mathrm{Cr}$ on ruminants.

The $\mathrm{K}$ concentration in blood tended to be constant, however, no differences between treatments for $\mathrm{K}$ of plasma or $\mathrm{Na}$ (Table 1). This result showed that reabsorption of $\mathrm{Na}$ and $\mathrm{K}$ may 
be decreased due to a concentration gradient favoring net diffusion of $\mathrm{Na}$ from interstitial fluid to lumen of renal tubular cells. Nevertheless, the level of haematochemical were normal showing that $\mathrm{Na}$ and $\mathrm{K}$ play a role to glucose transport. Kumar et al. (2010) stated that the glucose is cotransported with $\mathrm{Na}$ across the apical plasma membrane into the epithelial cell. It moves through the cell to the basal surface, where it passes into the blood via Glutation-2, a passive glucose uniporter. The Na- K-ATPase continues to pump $\mathrm{Na}$ outward to maintain the $\mathrm{Na}$ gradient that drives glucose uptake.

Although the organic-Cr dietary supplementation did not effect directly on the blood electrolyte, but this study showed that organic-Cr play role the general metabolism, especially water turn over to maintain the $\mathrm{Na}$ and $\mathrm{K}$ level in the blood plasma.

\section{CONCLUSIONS}

The $3 \mathrm{ppm}$ of organic-Cr supplementation in diet did not influence on stress response of transport-stressed beef cattle, included the some physiological condition, haematochemical and body weight loss due to transportation for seven hours. beef cattle fed on control diet (without $\mathrm{Cr}$ ) showed a stress symptom, their loss of body weight were higher $(5.41 \%)$ compared to beef given diet contains organic-Cr $(3.72 \% ; 5.04 \%$ and $4.83 \%$, respectively for $\mathrm{R} 1, \mathrm{R} 2$ and $\mathrm{R} 3$ ).

\section{ACKNOWLEDGMENT}

This research was a part of "Hibah Andalan of Unpad at Year 2009" which was fully expensed by DIPA University of Padjadjaran with contract number: 236/H6.1/Kep/HK/2009. The authors would like to thanks to Rector Unpad and chief of LPPM Unpad to the opportunity of conducting this research and also to PT. Citra Agro Buana Semesta for providing beef cattle and other facilities for this research.

\section{REFERENCES}

Al-Muffarej, S.I., I.A. Al-Haidary, M.S. AlKraides, M.F. Hussein and H.M. Metwally. 2008. Effect of chromium dietary supplementation on the immune response and some blood biochemical parameters of transport-stressed lambs. Asian-Aust. J. Anim. Sci. 21:671-676

Al-Saiady, M.Y., M.A. Al-Shaikh, S.I AlMuffarej, T.A. Al-Showeimi, H.H. Mogafer and A. Dirrar. 2004. Effect of chelated chromium supplementation on lactation performance and blood parameters of Holstein cows under heat stress. Anim. Feed Sci. and Technol. 117:223-233

Anderson, R.A. and A.S. Kozlovsky. 1985. Chromium intake, absorption and excretion of subject consuming sel-selected diets. Am.J. Clin. Nutr. 41:1177-1183

Araujo, B.D., R. F. Cooke, G. R. Hansen, C. R. Staples and J. D. Arthington. 2010. Effects of rumen-protected polyunsaturated fatty acid supplementation on performance and physiological responses of growing cattle after transportation and feedlot entry. J. Anim. Sci. 88:4120-4132

Chang, X. and D. N. Mowat. 1992. Supplemental chromium for stressed and growing feeder calves. J. Anim. Sci. 70:559-565

Colditz, I. G. and D. W. Hennessy. 2001. Associations between immune system, growth and carcass variables in cattle. Aust. J. Exp. Agric. 41:1051-1056

Eicher, S. D. 2001. Transportation of cattle in the dairy industry: current research and future directions. J. Dairy Sci. 84:E19-E23

Feuz, D. M. and W. J. Umberger. 2003. Beef cowcalf production. Vet. Clin. North Am. Food Anim. Pract. 19:339-363

Fike, K. and M.F. Spire. 2006. Transportation of cattle. Vet. Clin. North Am. Food Anim. Pract. 22:305-320

Gupta, S., B. Early and M.A. Crowe. 2007. Effect of 12-hour road transportation on physiological, immunological and haematological parameters in bulls housed at different space allowances. Vet. J. 173:605616

Kannan, G., T. H. Terrill, B. Kouakou, O. S. Gazal, S. Gelaye, E. A. Amoah and S. Samake. 2000. Transportation of goats: effects on physiological stress responses and live weight loss. J. Anim. Sci. 1450-1457

Kegley, E.B., D. L Galloway, and T. M. Fakler. 2000. Effect of dietary chromium-Lmethionine on glucose metabolism of beef steers. J. Anim. Sci. 78:3177-3183

Knowles, T. G., P. D. Warriss, S. N. Brown and J. E. Edwards. 1999. Effects on cattle of transportation by road for up to 31 hours. 
Vet. Rec. 145:575-582

Knowles T.G. and P.D. Warriss. 2000. Stress Physiology of Animals During Transport. $2^{\text {nd }}$ Ed. CAB Intenational.

Kumar, B.V.S., G. Singh and S. K. Meur. 2010. Effects of addition of electrolyte and ascorbic acid and feed during heat stress in buffaloes. Asian-Aust. J. Anim. Sci. 23:880888

Linder, M.C. 1992. Biokimia dan Metabolisme. UI Press. Jakarta.

McNamara1 J. P. and F. Valdez. 2005. Adipose tissue metabolism and production responses to calcium propionate and chromium propionate. J. Dairy Sci. 88:2498-2507

Mertz, W. 1993. Chromium in human nutrition: A review. J. Nutr. 123:626-633

Mustafa-Tehrani, A, G. Ghorbani, A. ZhareShanneh and S. Mirhadi. 2006. Non-carcass component and wholesale cut of Iranian fattailed lamb fed chromium nicotinante or chromium chloride. Small Ruminant Res. 63:12-19

Nairab, A. and R.H. Bonneaub. 2006. Stressinduced elevation of glucocorticoids increases microglia proliferation through NMDA receptor activation. J. of Neoroimmun. 171:72-85

Odore, R., A. D'Angelo, P. Badino, Bellino, S. Pagliasso and G. Re. 2004. Road transportation affects blood hormone levels and lymphocyte glucocorticoid and betaadrenergic receptor concentrations in calves. Vet. J. 168:297-303

Parker, A. J., G. P. Hamlin, C. J. Coleman, and L. A. Fitzpatrick. 2003. Dehydration in stressed ruminants may be the result of a cortisolinduced diuresis. J. Anim. Sci. 81:512-519

Parker, A. J., G. P. Dobson and L. A. Fitzpatrick. 2007. Physiological and metabolic effects of prophylactic treatment with the osmolytes glycerol and betaine on Bos indicus steers during long duration transportation. J. Anim. Sci. 85:2916-2923

Regmi, P.R., W. T. Dixon and M. Oba. 2008. Effects of ammonia load on glucose metabolism by isolated ovine duodenal mucosa. J. Anim. Sci. 86:2321-2327

SPSS. 2004. Sigma Plot for Windows. Ver 13.0. SPSS, Inc., Chicago. Ill.

Steel, R.G. and J.H. Torrie. 1981. Principles and Procedure of Statistics. $2^{\text {nd }}$ Ed McGraw-Hill
International Book Co., Singapore.

Stanger, K. J., N. Ketheesan, A. J. Parker, C. J. Coleman, S. M. Lazzaroni and L. A. Fitzpatrick. 2005. The effect of transportation on the immune status of Bos indicus steers. J. Anim. Sci. 83:2632-2636

Swanson, J. C. and J. Morrow-Tesch. 2001. Cattle transport: historical, research, and future perspectives. J. Anim. Sci. 79(E. Suppl.):E109-E109

Tyler, P. and K. A. Cummins. 2003. Effect of dietary ascorbyl-2-phosphate on immune function after transport of a feeding facility. J. Dairy Sci. 86:622-629

Van de Ligt, C.P.A, M.D. Lindermann and G.L.Gromwell. 2002. Assessment of chromium tricopicolinate supplementation and dietary protein level on growth, carcass, and blood criteria in growing pigs. J. Anim. Sci. 80:2414-2419

Vincent, J. B. 2004. Recent developments in the biochemistry of chromium (III). Biol. Trace Elem. Res. 99:1-16

Wang, M. Q. and Z. R. Xu. 2004. Effect of chromium nanoparticle on growth performance, carcass characteristics, pork quality and tissue chromium in finishing pigs. Asian-Aust. J. Anim. Sci. 17:1118-1122

Wang, M. Q., Z. R. Xu, L. Y. Zha and M. D. Lindemann. 2007. Effects of chromium nanocomposite supplementation on blood metabolites, endocrine parameters and immune traits in finishing pigs. Anim. Feed Sci. Technol. 139:69-80

Wang, M. Q, Y. D. He, M. D. Lindemann and Z. G. Jiang. 2009. Efficacy of $\mathrm{Cr}$ (III) Supplementation on Growth, Carcass Composition, Blood Metabolites, and Endocrine Parameters in Finishing Pigs. Asian-Aust. J. Anim. Sci. 22: 1414 - 1419

White, B.J., D. Blasi, L. C. Vogel and M. Epp. 2009. Associations of beef calf wellness and body weight gain with internal location in a truck during transportation. J. Anim. Sci. 87:4143-4150

Yang W.Z., D.N. Mowat, A. Subiyanto, R.M. Liptrap. 1996. Effects of chromium supplementation on early lactation of holstein cows. Can. J. Anim. Sci. 76:221-230

Zha, L.Y., M. Q. Wang, Z. R. Xu and L.Y. Gu. 2007. Efficacy of chromium (III) supplementation on growth, body composition, serum parameters, and tissue 
chromium in rats. Biol. Trace Elem. Res. 119:42-50

Zheng, P., Bing Yu, Mei Lv and D. Chen. 2010.
Effects of oxidative stress induced by diquat on arginine metabolism of postweaning pigs. Asian-Aust. J. Anim. Sci. 23:98-105 